\title{
Taboo Words Found in Crank High Voltage Movie Script
}

\author{
I Nengah Mileh ${ }^{1}$, Dewa Ngakan Putu Bayu Miarta ${ }^{2}$ \\ \{nengahmileh@gmail.com¹, bayumiarta@gmail.com ${ }^{2}$ \} \\ ${ }^{12}$ Faculty of Letters, Universitas Warmadewa Denpasar-Bali, Indonesia
}

\begin{abstract}
This movie was directed and written by Mark Neveldine and Brian Taylor. The aims of this study are to identify and classify the types and the functions of taboo words in the Crank High Voltage movie script. This study applied a qualitative descriptive method and documentation is used in collecting the data. All the data were collected from the movie script of Crank High Voltage. They were identified and classified based on the types and function according to the theory of Wardhaugh (2006) and Jay (1992). Documentation method was applied to collect all the data from the movie script. It was done in some stage as it follows: watching and reading the movie script, then the selected word was quoted and classified based on the type and function. Finally, in accordance with the result, there are eight types of taboo word occurred. They are cursing, profanity, obscenity, vulgarity, slang, epithets, insult and slurs, and scatology. There is four functions of taboo word as it follows: to draw attention to oneself, to show contempt, to be provocative, and to mock authority. In conclusion, the function of taboo words that mostly appear in this study is the function to show contempt and followed by the function of to be provocative.
\end{abstract}

Keywords - Taboo words, types of taboo words, functions of taboo words

\section{Introduction}

In the normal transfer of information through language, we use it to send vital social messages about who we are, where we come from, and who we associate with. In several occasions, some words can be extensively clean or no limit or forbidden to say and there is some of them are believed to be dirty or harm to say that it can give a negative meaning to the addressee. It is often shocking to realize how extensively we may use to judge and person's background, character, and intentions based simply upon the person's language, dialect, or in some instance even the choice of a single word. The taboo word cannot be separated in our daily life that without realizing it. It is widely used in many language contacts. These unique tools are used by many different backgrounds of people in their daily conversation. This certain words in all societies are considered as taboo in that they are not to be used especially in polite situation. It clearly shows that because of the strong emotion carried by the word taboo, it cannot mostly say in every situation. In certain societies, these words used in some circumstances, that refer to the activities that are forbidden or to be avoided. Words relating to 
sex, sex organs, religious connotation and others often used by many people to give vent to strong emotion. These certain words are considered as Taboo. The functions are to draw attention to oneself, to show contempt, to be aggressive or provocative, and to mock authority. The uses of taboo in daily conversation are varied and to be closely related to the acts that prohibited or avoided to do. For example, words carried religious connotation or offending the God, holy book and else are considered profane if it is used outside the ceremonies. Especially for us in Asian culture are not permitted to use taboo word in daily conversation.

Moreover, the existence of taboo word can be found in various sources such as in the movie, song lyric, etc. especially in the movie, the existence is caused by the fact that the characters need to express a strong feeling and emotion by the word taboo. It is uttered to shows anger, frustration, express friendliness, familiarity, and etc. For instance, the sentence "hey you cunt" the word cunt means "friend". Usually, it is uttered by people to call their close friend or their close family member, but the word above can also mean the derogatory term for a woman in other circumstances. Some latest related studies that concerned with this present study, such as [1] a research study entitled "The Use of Taboo Words in Pak Darto Character in Tendangan Dari Langit Movie" showed that it was found 10 utterances containing Javanese taboo words by Pak Darto. The writer found that Pak Darto used 5 types of taboo words to express his feelings, they are one's mother in law, bodily function/human genitals term, death, excretion and creating game/animal. Furthermore, Pak Darto only had 4 purposes in using the taboo words, namely to discredit, to provoke violent confrontation, to an endearment and to provide catharsis. Anggita's research [2] entitled "A Sociolinguistic Analysis of Taboo Words in Bad Teacher Movie" showed that there were four types of taboo words found in the movie. They were obscenity, profanity, vulgarity, and epithet. In addition, the characters in Bad Teacher movie employed taboo words for four functions in their utterances. They were to draw attention to oneself, to show contempt, to be provocative, and to mock authority. Furthermore, [3] the similar study conducted entitled "An Analysis of Taboo Words in Wild Child Movie", showed results that firstly, there are five forms of abusive language in this movie, they are: animal terms of abuse, sexist terms of abuse, racist terms of abuse, homophobic terms of abuse, and intellect- based terms of abuse. Secondly, the difference between the use of taboo words by the British and Americans in this movie is just on the expression, British people prefer to use straightforward words or meaningful corresponding original words, while Americans prefer to use words figuratively although, it does not distinguish intensity all the rage. i.g. the American people prefer to use the figurative language just like gross, horridious cow, horse face, dweep, and excellent shreck. However, British prefer to use straightforward like nightclub, dogs, Vermin, slutty, whore-y, and rotting pig's vomit. Thus, this study aims to identify and classify the types and the function of taboo words in the Crank High Voltage movie script since there are many characters frequently used taboo words as their conversation so that the utterances are analyzed. In addition, the characters come from bad educational background as the story begins on the street gang setting.

\section{Method}

The data of this study were taken from "Crank 2 High Voltage" movie script which directed and written by Mark Neveldine and Brian Taylor. The script was downloaded from website https://subscene.com/subtitles/crank-2-hight-voltage/english/1166630. It is an American crime film, which center on a brutal gang war member of Chev Chelios to take back his heart that 
stolen by Chinese TRIAD gang and fight with Mexican gang member EL Huron, and various other media portraying the characters and situations from the films. Documentation is used in collecting the data. Moreover, the data were analyzed based on the theories used in this study. The data were analyzed by using a descriptive method which means that all the data collected were descriptively analyzed by giving some examples and explanation based on the theories concerned.

\section{Results And Discussion}

As mentioned previously that this study aims to analyze taboo words occurred in the Crank 2 High Voltage movie script based on the types and function of each word. Based on the analysis, it was found the types and functions of taboo words in the Crank High Voltage movie script. It can be seen in the following explanations.

A. The Types of Taboo Words in Crank 2 High Voltage

The taboo words were found in the Crank 2 High Voltage movie script. The data were classified based on the categories [4]. As a result of the analysis, the taboo words found are cursing, profanity, obscenity, vulgarity, slang, epithets, insult and slurs, and scatology. Further discussions are presented in the following discussion.

\section{Cursing}

The use of cursing is to harm another person by religious or social demarcation. Based on the analysis, there is only one cursing found in the data. The example is as follows:

Goddamn (00:18:40,401)

$\begin{array}{ll}\text { RIA } & \text { : Hey, dude why you in rush? } \\ \text { RIA } & \text { : Wait for me! } \\ \text { DRIVER } & \text { : Goddamn! } \\ \text { DRIVER } & \text { : Get out off me } \\ \text { CHELIOS } & \text { : Get out of the fucking car! }\end{array}$

Based on the data above, the cursing expression goddamn was uttered by the character from the movie that is a driver who expresses his anger feeling toward Chelios. It can be seen from the movie when the driver drives his car, Chelios is trying to steal his car. This situation annoyed the driver. This is why the driver launches the word of cursing goddamn to express his anger feeling and harm the Chelios in order to stop trying to steal his car. This is in the line with the characteristic of cursing which here the word religious belief used to harm or punishing somebody.

2. Profanity

Profanity means to be ignorant of the words in religious belief, and this seeks not to denigrate God, religion or holy affairs but would be based more on ignorance or indifference to this matter. It can be seen in the following example.

Jesus H...Chelios! (00:11:15,523)

$\begin{array}{ll}\text { CHELIOS } & \text { : Hello. Doc Miles. } \\ \text { CHELIOS } & \text { : Yeah... Doc, it's Chev. } \\ \text { DOC MILES } & \text { : Jesus H... Chelios! } \\ \text { DOC MILES } & \text { : You've gotta be kiddin' me. }\end{array}$

In the example above, the profane word was uttered by character Doc Miles the specialist doctor of Chelios. The expression above belongs to profanity since it showed the ignorant of the character of the movie by using words related to religious belief. It could be seen on the 
data above that character Doc Miles used the expression of religious belief Jesus H... to express his feeling of disbelief to the situation of the situation when Chelios call him, Doc Miles know that Chelios has died 3 months ago because of helicopter accident, and now Chelios call him and he shocked of that situation.

3. Obscenity

The meaning of the word obscene is same as indecent. It is considered to be offensive and repulsive word ever used. The following example is the obscenity example found in the data.

Motherfuckers (00:11,20,829)

DOC MILES : Jesus H... Chelios!

DOC MILES : You've gotta be kiddin me.

CHELIOS : Listen, I'm deadly fuckin serious, Doc.

CHELIOS : These Triad motherfuckers cut out my fuckin heart

CHELIOS : And put in one of those plastic artificial jobs.

DOC MILES : You got an artificial heart?

CHELIOS : Do you think I'm having a fuckin laugh?

In the example above, the obscene above was uttered by the main character Chelios. $\mathrm{He}$ launched the offensive obscene word motherfucker to the Triad gangster. Here, it can be seen on the scene that feeling anger to Triad gangster because those Triad gangsters cut out his heart and changed his heart with an artificial heart (heart with battery power). The word motherfucker is considered obscene or indecent because of the meaning is a guy who likes to have sexual activity with his mother. This word is categorized as obscenity because it is appropriate to the character above.

4. Vulgarity

It usually used to show the crudeness of the person that launched this vulgar word. This word was used by a person to offend someone. The example is presented below.

Asshole $(00: 32: 16,149)$

$\begin{array}{ll}\text { DOG WALKER } & \text { : See? Way better than a cat man } \\ \text { DOG WALKER } & \text { : Whatever } \\ \text { DOG WALKER 2 } & \text { : Who is this fuckin asshole? } \\ \text { CHELIOS } & \text { : You pair of sausage niggles } \\ \text { CHELIOS } & \text { : How do you sleep at night? } \\ \text { DOG WALKER } & \text { : Who is this guy? } \\ \text { CHELIOS } & \text { : I'm from PETA }\end{array}$

In the example above, the word asshole was uttered by a couple of dog walker it refers to Chelios who come after him with the panic situation. This expression is appropriate with the characteristic of vulgarity because the word asshole was used to offend the addressee and show the crudeness of the situation.

5. Slang

Slang is a vocabulary that is developed in certain sub-group (teenager, musicians, soldiers, drug user, or athletes) for ease communication. It is used to identify the member of the group and commonly found in spoken also not suitable for a formal situation. The following example is slang example found in the data.

Bitch $(00: 28: 53,580)$

FEMALE PORN STAR: Do you gonna put Johny Vang on ice?

CHELIOS : Maybe

FEMALE PORN STAR: That's so fuckin sexy

EVE : Didn't they cuff you?

EVE : Damn it. Do me 
FEMALE PORN STAR: I'll do you

EVE : Bitch

In the example above, the setting of the scene was inside the car. The word bitch here uttered by female character Eve. The female character Eve just got arrested in a police car with female porn star in Cypress Social Club. In this scene, Eve had a conversation with female porn star, when she cuff of by the police, the female porn star can release the cuff, and the female character Eve ask help to release her cuff to, when her cuff was opened, Eve beat the female porn star with her head and says bitch to female porn star. The word bitch means female got or an offensive way of referring a woman, especially unpleasant one. Here, this word is appropriate with characteristic of slang since Eve used it to identify the female porn star. The meaning of the word was taken from Oxford advanced learner's dictionary.

6. Epithets

This type is powerful but the burst of emotional language. Epithets are usually uttered from feeling of frustration. For instance is when your hand hit by a hammer also when joking. The example can be seen as follows.

Shit $(00: 08: 33,495)$

$\begin{array}{ll}\text { CHELIOS } & \text { : What I need from you is directions. } \\ \text { CHELIOS } & \text { : Oh, shit. } \\ \text { MEXICAN GUY } & \text { : Damn, dog. are you good esse? } \\ \text { CHELIOS } & \text { : Tiger fuckin woods } \\ \text { CHELIOS } & \text { : Never better. Greatest day of my fuckin life. }\end{array}$

In example (1) the word shit above was launched by main character Chelios. It happens when his car crashed, and makes him flung away and fall in the street. The word shit means an act of defecating or faeces. It takes from Oxford advance learner's dictionary. This kind of word was uttered by main character Chelios to show his burst emotional feeling off crashed. It is appropriate with characteristic of epithets explanation above.

7. Insult and Slurs

Insult and slurs are kind of word used to harm another person by the word alone. Slurs may be facial, ethnic, and social in nature while insult may denote the physical, mental, or psychological qualities of the target. They both function to hurt the person directly through a particular word or phrases. Some insults and slurs may use animal imagery also some are based on social deviations. It can be seen in the following example.

Bastard (00:25:12,393)

CHELIOS

MEXICAN GANGSTER

CHELIOS

MEXICAN GANGSTER

MEXICAN GANGSTER

CHELIOS

MEXICAN GANGSTER

CHELIOS

\author{
: Who do you work for and what do they want with me? \\ : El Huron \\ : English! What's a fuckin ''El who done? \\ : it's a ferret. \\ : He wants you alive. So he can watch you die \\ : Oh, yeah? Why? \\ : I don't know. Doesn't everybody? \\ : Shut up. Oo, you lucky bastard
}

In the example above, the setting of this scene was inside Cypress Social Club. The main character Chelios had a gunfight with Mexican gangster when he got defeated the Mexican gangster. The main character Chelios had a conversation with a dying Mexican gangster member. After the conversation Chelios is trying to kill the Mexican gangster member, his gun out of ammo, and Chelios says you lucky bastard. The word bastard literally means a son of a bitch, natural child, or the boy who born from prostitute mother. 


\section{Scatology}

The scatological terms refer to human waste product or processes. If it is simplified, this is such that use to teach children about toilet trained. The example can be seen in the following.

Shit (00:12:00,935

DOC MILES : Does-does- let me-does that thing have a a-a-a a belt Battery pack?

CHELIOS : Check

DOC MILES : How many bars are showing?

CHELIOS : One

DOC MILES : Shit. That's better than none, I guess.

B. Function of taboo word in Crank 2 High Voltage

The taboo words found in Crank 2 high voltage movie script. The data were classified based on the function [5]. From the data collected, taboo words that appropriate with the function were presented below.

1. To draw attention to oneself

The speaker should gain interest through the use of strong, powerful language whose connotation can stimulate an instant reaction from the audience (Edward, 1973). One of the languages is taboo word. It is uttered to catch attention from the addressee. Here below example of the function occurred in the Crank 2 High Voltage.

Damn (00:13:12,904)

$\begin{array}{ll}\text { CHELIOS } & \text { : Shit } \\ \text { MEXICAN GUY } & \text { : Damn, dog you good else? } \\ \text { CHELIOS } & \text { : Tiger fuckin woods } \\ \text { CHELIOS } & \text { : Never better. Greatest day of my fucking life. }\end{array}$

In the example above, the word of profanity damn above was uttered by character Mexican guy in order to get quick response or in another word to draw Chelios attention in this case. On the scene, the speaker tries to get a clarification about what he has seen, the Mexican guys try to ask about the main character Chelios about his condition after have a car accident. This is why he used the taboo word in the function to draw attention to oneself to get his attention.

2. To show contempt

To show contempt means the impression in which a person or maybe something is totally useless and cannot be regarded. Here below example of function to show contempt found in Crank 2 High Voltage.

Whore (00:22:59,827)

EVE : Who the fuck is that?

CHELIOS : Ah, some whore

CHELIOS : Fuck, no

CHELIOS : That was a mistake

In the example above, the word slang whore above was uttered by the speaker to contempt his addressee. It can be seen on the scene, where main character Chelios argued with his girlfriend talking about who is another woman beside him, Here the main character says to his girlfriend, the woman beside him is another whore, whore means a prostitute woman. This word used to identify woman beside him. The word of slang above is used to show contempt since it appropriate with characteristic.

3. To be provocative

The meaning of provocative is causing anger or another strong reaction. Taboo word is uttered to provoke hearer's anger or intent to get a certain response like violation or other. Here below example of the function to be provocative found in the Crank High Voltage Movie Script. 
Tits $(00: 31: 09,449)$

$\begin{array}{ll}\text { DEMONSTRATOR (girl) } & \text { : Pay my fuckin wages, mother fuckers } \\ \text { DEMONSTRATOR (man) } & \text { : Droppin loads on all of your silly wages! } \\ \text { PORN STAR } & \text { : They need their money } \\ \text { DEMONSTRATOR (man) } & \text { : What do you want me to fuck this car? } \\ \text { DEMONSTRATOR (girl) } & \text { : Suck my fuckin tits! } \\ \text { CHELIOS } & \text { : Get off the car }\end{array}$

In the example above, this obscenity word is an offensive utterance was also used by the speaker as the function to provoke the addressee. The scene was on the street with a crowd of demonstrators, the demonstrator got argues with Chelios. Here is the following part of the conversation, The conversation above shows us the demonstrator launched the word suck my fuckin Tits to Chelios to provoke his anger, because of that words main character Chelios finally got upset. The meaning of the word tits is a couple of female breasts. Again, this kind of word is considered to be obscene to provoke because the meaning of the word that should not utter in accordance the indecency.

4. To mock authority

There is a function to mock authority which means a behaviour to tease or jest a person or organization having political or administrative power and control. Here below is the example of the function found in Crank high voltage movie script.

Motherfucking (00:44:26,112)

DON KIM : Chev chelios.

CHELIOS : Don motherfucking kim.

CHELIOS : Looks like you pulled my little white ass out of the hot grease again .

DON KIM : Please... don't thank me.

CHELIOS : I don't think I shall

CHELIOS : Now, I'm not sure if you're aware of this jeeves, but your slant-eyed associates have taken something extreme value to me.

In the example above, this function was used by the speaker to mock his addressee. On the conversation above, it can be seen that the male character Chev Chelios jest his friend Don Kim using the word motherfucking which known as the word refer to a guy who has sexual activity with his mother. This word was just used to mock his target with angry feeling. This is appropriate with the characteristic of the function to mock authority that been explain in the earlier chapter.

\section{Conclusion}

Based on the analysis and the discussion of the types and functions of taboo words above, thus it can be concluded that there are eight types of taboo words were occurred in the Crank High Voltage movie script. They are cursing, profanity, obscenity, vulgarity, slang, epithets, insult and slurs, and scatology. Three types of taboo words such as slang, obscenity and vulgarity were dominantly found in this study. Furthermore, there are four functions of taboo words were occurred in this study. Those are to draw attention to oneself, to show contempt, to be provocative and mock authority. The function of taboo words that mostly appear in this study is the function to show contempt and followed by the function of to be provocative. 


\section{Reference}

[1] C. Chotimah, "The Use of Taboo Words in Pak Darto Character in Tendangan Dari Langit Movie," Jurnal Ilmiah Mahasiswa FIB, vol. 5, no. 10, 2014.

[2] F. N. Anggita, "A Sociolinguistic Analysis of Taboo Words in Bad Teacher Movie," Quill Bahasa dan Sastra Inggris, vol. IV, no. 1, pp. 1-18, 2017.

[3] M. D. Ihsan, "An Analysis of Taboo Words in Wild Child Movie," Aesthetics: Jurnal Fakultas Sastra Universitas Gresik, vol. 6, no. 1, 2017.

[4] T. Jay, Cursing in America: A Psychological Study of dirty language in The Courts, in The Movies, in The Schoolyards and on The Street. Philadelphia: John Benjamin Publishing Co., 1992.

[5] R. Wardaugh, An introduction to Sociolinguistics. Cambridge: Blackwell Ltd, 2006. 